\title{
Assessing the Real Risk of Mining Industry Environmental Impact. Case Study
}

\author{
Wiktoria SOBCZYK ${ }^{1)}$, Koji Cristobal Ishimi PERNY2), Eugeniusz J. SOBCZYK ${ }^{3)}$
}

\footnotetext{
1) Department of Environmental Engineering, Faculty of Mining and Geoengineering, AGH University of Science and Technology, 30059 Kraków, Poland; sobczyk@agh.edu.pl (W.S.); email: sobczyk@agh.edu.pl

2) Department of Environmental Engineering, Faculty of Mining and Geoengineering, AGH University of Science \& Technology; Universidad Politécnica de Madrid; koji.ishimi.perny@alumnos.upm.es (K.C.)

${ }^{3)}$ Mineral Energy and Economy Research Institute of the Polish Academy of Sciences, J. Wybickiego 7, 31-261 Krakow, Poland (E.S.)
}

http://doi.org/10.29227/IM-2021-01-05

Submission date: 28-01-2021 | Review date: 21-05-2021

\section{Abstract}

The aim of this article is to analyse the real risk that mining operations pose to the environment, including all the main concerns related to the project's planned operations and their environmental impacts. In order to carry out an in-depth analysis of a practical case involving the real process of mineral extraction, we use the Analytic Hierarchy Process (AHP) and Leopold matrix as a method of measurement. The subject of the investigation is the extraction of lithium from natural brine located in South America's so-called Lithium Triangle, in the geographical limits of Argentina, Bolivia and Chile, where more than 80\% of the world's lithium reserves are located. The case study showed that the elements of the environment most exposed to mining activities are the biosphere, lithosphere and hydrosphere. The vast areas of the mining company are covered by sedimentary ponds with brine. Pumping the brine to the surface results in a loss of groundwater resources and, consequently, changes the water cycle in the catchment area. The habitats of aquatic and terrestrial fauna and flora are significantly changed or irretrievably damaged.

Keywords: mining activities, lithium, environment, AHP, Leopold matrix

\section{Introduction}

Mining and metallurgic industries are one of the most influential pillars of the economy; not only do they satisfy material needs of the industrialized world, but they also ensure and support the growth of developing countries. Materials and products consumed by the countries, especially those which are still developing their economy and basic needs, are provided directly or indirectly through their extraction by the mining sector from the natural environment. Mining is also considered to play an important role in the economy at a local level due to a growing number of investment projects and job opportunities on the market [1]. Extracting and exploiting its own mineral resources is a very profitable option for a country to boost its economy whenever the treatment and transformation to consumer goods is not possible or not efficient enough $[2,3]$. On the other hand, mining has a very negative image from the social and cultural point of view as it is associated to high contamination level and degradation of the biosphere due to the uncontrolled human activity and its adverse effects on the environment. These socio-cultural attitudes cannot be ignored and must be looked at closely to help the industry develop and change its negative image [4]. It is necessary to point out that even though the preservation of the environment is a crucial and very important aspect, it is not the only factor that determines the social acceptance of the extractive industry. On many occasions both parties (mining corporations and social communities) see a mutual interest. This applies to land acquisition, payments for the use of water, presence of subcontractors, compensation, local purchases, social investment strategies, etc. In order for mining to become socially acceptable, it is important not to overlook the initiation of measures at legislative level, the effective implementation of measures to protect against the effects of mining activities and ethical motivation when designing the processes involved. The biosphere is intrinsically exposed to the effects of mining activities, therefore every mining project must take into consideration the management of the effects they cause to the environment, starting with design and business decisions. The industry must ensure that the environment is protected; it needs to be the main step in a typical cycle of mining activities (prospecting/exploration, development, mineral extraction, metallurgic process and closure/ reclamation) [1,5-7].

Argentina, Bolivia, and Chile have approximately $75 \%$ of the world's lithium brine reserves in the area known as the lithium triangle. Currently, lithium can be extracted from three different types of deposits: brine (as in Chile, Bolivia and Argentina), pegmatite (hard rock) and sedimentary deposits, each requiring different types of extraction and processing methods. Today, the first two types are the most commonly used for commercial lithium production. Lithium is used in a variety of products and in different industrial areas; more traditional uses include applications in ceramics, glass and medicine [8,9]. More recent areas of use include applications such as lithium-ion batteries used in small electronic devices, or larger batteries used in electric and hybrid cars. Future uses include the production of nuclear energy through nuclear fusion, an area currently under investigation.

The process for converting brine to high-purity lithium carbonate follows industry standards: pumping brine from the salar (salt flat), concentrating the brine through evaporation ponds and taking the brine concentrate through a hydrometallurgical facility to produce high-grade lithium carbonate. The basic process inputs include evaporated brine, water, 


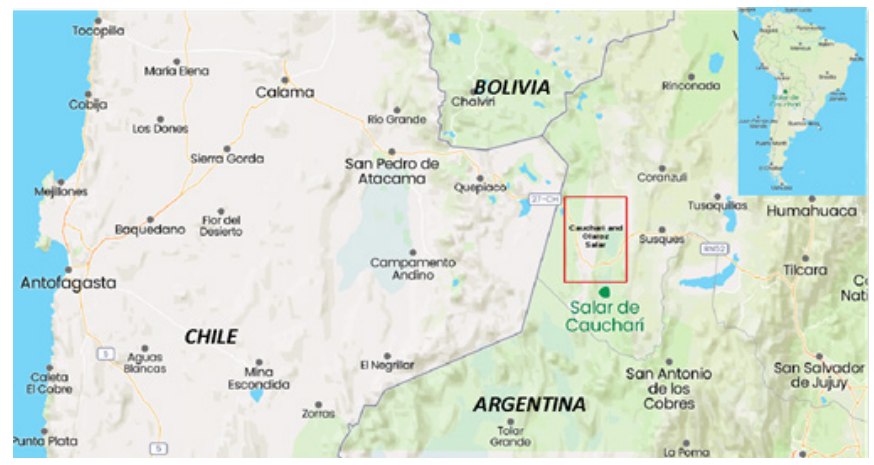

Fig. 1. Location of the mine (Source: own study based on https://mapcarta.com)

Rys. 1. Lokalizacja kopalni (Źródło: opracowanie własne na podstawie https://mapcarta.com)

lime, soda ash, $\mathrm{HCl}, \mathrm{NaOH}$, and natural gas. The evaporation ponds produce salt tailings composed of $\mathrm{Na}, \mathrm{Mg}, \mathrm{Ca}, \mathrm{K}$, and borate salts. The brine concentrate from the terminal evaporation pond is further processed, through a series of polishing and impurity removal steps [10]. Soda ash is then added with the purified brine concentrate to produce lithium carbonate that is dried, micronized, and packaged for shipping. The lithium recovery process consists of the following main processing stages: brine production from wells, sequential solar evaporation, pond-based impurity reduction by liming, plant-based impurity polishing, lithium carbonate precipitation, mother liquor treatment and recycle, lithium carbonate crystal compaction and micronization, lithium carbonate packaging $[11,12]$.

The current process design, based on testing and simulation, has been enhanced with: pond-based sulphate and boron reduction, plant-based potassium chloride reduction, mother liquor re-concentration. Then the brine is pumped from the salar into the pond system. As it progresses through the ponds, different salts precipitate, and chemical treatments are applied [13].

\section{Study case}

\section{Location of the mine}

The case under study is the production of lithium carbonate by Lithium Americas at the Cauchari and Olaroz Salars, located in the Jujuy province, in the Department of Susques, north-western Argentina. The nearest port is Antofagasta in Chile located $530 \mathrm{~km}$ to the west of the salars by road. The salars are located in the area known as "Lithium Triangle", which refers to the territory shared by Chile, Argentina and Bolivia, where more than three quarters of the world's lithium supply is entrapped underneath their salt-rich soil. In desert climates lithium brines are formed due to a slow inflow of lithium, other metals and salts; since there is no outflow, gradual evaporation over long periods of time (thousands of years) slowly increases lithium concentrations to an economic level [14].

The lithium is extracted from the brine under the surface. The brine is contained within the pore space of alluvial, lacustrine, and evaporite deposits that have accumulated as a multi-layer aquifer in the structural basin of the salars. The brines from Cauchari are saturated in sodium chloride with total dissolved solids on the order of 27\% (324 to 335 grams per litter) and an average density of about 1.215 grams per cubic centimetre. The other primary components of these brines include potassium, lithium, magnesium, calcium, sulphate, $\mathrm{HCO}_{3}$, and boron as borates and free $\mathrm{H}_{3} \mathrm{BO}_{3}$ [15-17].

\section{Materials and Methods Methods Description}

To evaluate and analyse the environmental impact of the subject mine we apply the AHP and Leopold Matrix principles and techniques. The AHP acronym stands for Analytic Hierarchy Process and is a multi-criteria decision making method. It translates the value of the impacts into measurable numeric relations. The main characteristic of the method is the use of pairwise comparisons; in our case we compare the impact on different elements of the environment one by one, pair by pair, in order to create a hierarchy showing the importance of the impact on different elements (biosphere, atmosphere, lithosphere...), giving a reasonable explanation to every comparison $[18,19]$.

There are various stages involved in the process: 1 . Structure the multi-criteria problem in order to solve it in the form of a hierarchy by decomposing the general task into smaller and simpler components. The hierarchical structure can be shown as a pyramid where the summit hosts the main task, in this case "Assessment of the environmental impact of the mine"; 2. Design priorities to all of the components in the structure by assigning factor weights from 1 to 9 (table 1); then all the elements are compared and evaluated in pairs in order to specify their importance and find the most relevant element to achieve the main task; 3 . This stage aims at verifying the pairwise comparisons of each element. An advantage of using this hierarchical method is that errors are limited; 4 . Designation of priorities through weights assigned to different possibilities, classification of those possibilities, and their assessment in relation to their priority of implementation. Finally the analysed hierarchical model is completed, with a classification of priority vectors in the order of priority: the higher the value of the vector the more important the element is. By means of that model we can evaluate the whole project to make the best choices before starting any investment process $[20,21]$.

With the weights assigned to each element obtained from the AHP method, we proceed to the construction of a Leopold matrix. In this case we use balanced weights calculated by experts in the field. These weights represent the general hierarchical importance of the environmental elements affected by the mining project $[20,23]$. 
Tab. 1. Scale of degrees of preference for paired comparisons in the AHP method [22]

Tab. 1. Skala stopni preferencji dla porównań parami w metodzie AHP [22]

\begin{tabular}{|c|l|}
\hline $\begin{array}{c}\text { Degree of } \\
\text { importance }\end{array}$ & \multicolumn{1}{c|}{ Definition } \\
\hline 1 & The elements (features) are equally important \\
\hline 3 & A domination one element over other (second) is minimal \\
\hline 5 & A domination one element over other (second) is medium \\
\hline 7 & A domination one element over other (second) is big \\
\hline 9 & A domination one element over other (second) is very big \\
\hline $2,4,6,8$ & Indirect value between odd values \\
\hline
\end{tabular}

Tab. 2. Leopold matrix results (Source: own study)

Tab. 2. Wyniki macierzy Leopolda (Źródło: opracowanie własne)

\begin{tabular}{|c|c|c|c|c|c|c|c|c|}
\hline \multirow{4}{*}{$\begin{array}{c}\text { The impact of } \\
\text { the mine on } \\
\text { the } \\
\text { environment }\end{array}$} & \multirow{4}{*}{ Action } & \multicolumn{7}{|c|}{ Environmental elements $*$} \\
\hline & & L_sph & H_sph & At_sph & An_sph & B_sph & V_to_nh & Sum \\
\hline & & \multicolumn{7}{|c|}{ Importance } \\
\hline & & 0,261 & 0,194 & 0,059 & 0,046 & 0,29 & 0,151 & 1,0 \\
\hline \multirow{2}{*}{$\begin{array}{l}\text { Occupation } \\
\text { of Surface }\end{array}$} & $\begin{array}{l}\text { Magnitude } \\
\text { of impact }\end{array}$ & 2 & 0 & 0 & 0 & 1 & 0 & 3 \\
\hline & $\begin{array}{l}\text { Impact of } \\
\text { action }\end{array}$ & 0,522 & 0 & 0 & 0 & 0,228 & 0 & 0,75 \\
\hline \multirow{2}{*}{ Deforestation } & $\begin{array}{l}\text { Magnitude } \\
\text { of impact }\end{array}$ & 0 & 0 & 0 & 0 & 0 & 0 & 0 \\
\hline & $\begin{array}{l}\text { Impact of } \\
\text { action }\end{array}$ & 0 & 0 & 0 & 0 & 0 & 0 & 0 \\
\hline \multirow{2}{*}{$\begin{array}{l}\text { Infrastructure } \\
\text { of power plant }\end{array}$} & $\begin{array}{l}\text { Magnitude } \\
\text { of impact }\end{array}$ & 1 & 0 & 2 & 0 & 0 & 0 & 3 \\
\hline & $\begin{array}{c}\text { Impact of } \\
\text { action }\end{array}$ & 0,261 & 0 & 0,118 & 0 & 0 & 0 & 0,379 \\
\hline \multirow{2}{*}{$\begin{array}{l}\text { Noise and } \\
\text { Vibration }\end{array}$} & $\begin{array}{l}\text { Magnitude } \\
\text { of impact }\end{array}$ & 0 & 0 & 0 & 0 & 1 & 0 & 1 \\
\hline & $\begin{array}{c}\text { Impact of } \\
\text { action }\end{array}$ & 0 & 0 & 0 & 0 & 0,228 & 0 & 0,228 \\
\hline \multirow{2}{*}{$\begin{array}{l}\text { Water in the } \\
\text { manufacturing }\end{array}$} & $\begin{array}{l}\text { Magnitude } \\
\text { of impact }\end{array}$ & 0 & 5 & 0 & 4 & 4 & 1 & 14 \\
\hline & $\begin{array}{l}\text { Impact of } \\
\text { action }\end{array}$ & 0 & 0,97 & 0 & 0,184 & 0,912 & 0,151 & 2,217 \\
\hline \multirow{2}{*}{$\begin{array}{l}\text { Reclamation } \\
\text { Activities }\end{array}$} & $\begin{array}{l}\text { Magnitude } \\
\text { of impact }\end{array}$ & 0 & 0 & 0 & 0 & 0 & 0 & 0 \\
\hline & $\begin{array}{l}\text { Impact of } \\
\text { action }\end{array}$ & 0 & 0 & 0 & 0 & 0 & 0 & 0 \\
\hline \multirow{2}{*}{$\begin{array}{l}\text { Municipal } \\
\text { Wastes }\end{array}$} & $\begin{array}{l}\text { Magnitude } \\
\text { of impact }\end{array}$ & 2 & 0 & 2 & 0 & 1 & 0 & 5 \\
\hline & $\begin{array}{c}\text { Impact of } \\
\text { action }\end{array}$ & 0,522 & 0 & & 0,118 & 0 & 0,228 & 0,868 \\
\hline \multirow{2}{*}{$\begin{array}{l}\text { Industrial } \\
\text { Wastes }\end{array}$} & $\begin{array}{l}\text { Magnitude } \\
\text { of impact }\end{array}$ & 3 & 2 & 0 & 0 & 1 & 0 & 6 \\
\hline & $\begin{array}{l}\text { Impact of } \\
\text { action }\end{array}$ & 0,783 & 0,388 & 0 & 0 & 0,228 & 0 & 1,399 \\
\hline \multirow{2}{*}{$\begin{array}{l}\text { Unpleasant } \\
\text { Odors }\end{array}$} & $\begin{array}{l}\text { Magnitude } \\
\text { of impact }\end{array}$ & 0 & 0 & 0 & 0 & 1 & 0 & 1 \\
\hline & $\begin{array}{l}\text { Impact of } \\
\text { action }\end{array}$ & 0 & 0 & 0 & 0 & 0,228 & 0 & 0,228 \\
\hline \multirow{2}{*}{$\begin{array}{l}\text { Pollutant } \\
\text { emissions to } \\
\text { the air }\end{array}$} & $\begin{array}{l}\text { Magnitude } \\
\text { of impact }\end{array}$ & 0 & 0 & 2 & 1 & 1 & 0 & 4 \\
\hline & $\begin{array}{c}\text { Impact of } \\
\text { action }\end{array}$ & 0 & 0 & 0,118 & 0,046 & 0,228 & 0 & 0,392 \\
\hline \multicolumn{2}{|c|}{ Sum of Impact of action } & 2,088 & 1,358 & 0,236 & 0,348 & 2,052 & 0,379 & 6,461 \\
\hline
\end{tabular}

*L_sph - Lithosphere; $H \_s p h-H y d r o s p h e r e ; A t \_s p h-A$ tmosphere; An_sph - A ntroposphere; B_sph Biosphere; $V$ to nh-Vulnerability to natural hazards environment 


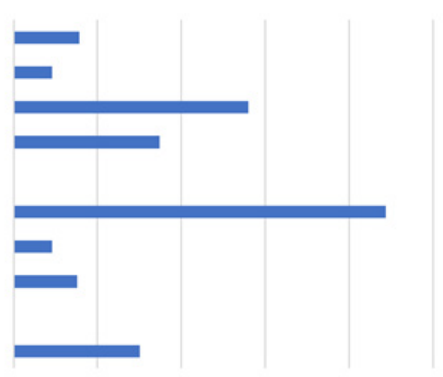

Fig. 2. Leopold actions results (Source: own study)

Rys. 2. Wyniki matrycy Leopolda (Źródło: opracowanie własne)

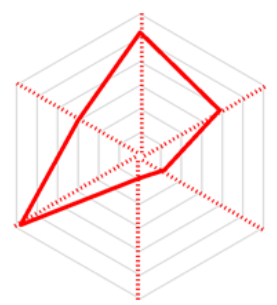

Fig. 3. Wind Rose. Leopold Elements Results (Source: own study)

Tab. 3. Róża wiatrów. Wyniki matrycy Leopolda (Źródło: opracowanie własne)

The Leopold matrix is a framework method that enables us to do the environmental risk assessment of a project, on the basis of criteria related to significance, probability, and duration of the impact. Similarly to the AHP, it belongs to the multi-criteria decision making methodology. It consists of a two-dimensional matrix where individual actions are assessed in relation to the actual environmental features and conditions that could be affected by the project's operations. In this method we use the weights obtained in the AHP as a reference in order to assess the actions that accompany the extractive activities and affect each element, so that we are able to create a specific hierarchy of elements affected and specify actions taking place within the scope of the mining project subject of the study $[24,25]$.

\section{AHP Analysis Method}

The main task of the analysis is the assessment of the environmental impact of the Cauchari-Olaroz project. The items subjected to priority analysis are the impacts on the following parts of the environment: lithosphere (solid, outer part of the earth), atmosphere (mixture of gases surrounding the earth), hydrosphere (all of the water, ice, and water vapour at or near the surface, such as the seas, clouds, and the water in and under the ground), biosphere (all type of life present), anthroposphere (part of the environment occupied, made or modified by humans for use in human activities and human habitats), vulnerability to natural hazards (natural physical phenomena caused by a fast or slow chain of events: earthquakes, landslides, tsunamis, extreme temperatures, etc.).

The analysis of the environmental impact of mining industry was carried out with the participation of experts selected according to their competences, which allowed to include all the elements needed to assess the analysed problem. The evaluations presented in the paper (pairwise comparisons with criteria and subcriteria based on a rating scale from 1 to 9 , the so-called Saaty scale) were carried out as part of a group decision making process, the so-called brainstorming. The authors of the paper were personally involved in the brainstorming session, and experts were selected from various fields of science: geology (7 mining geologists), mining (5 mining engineers), environmental management and engineering (4 experts), environmental protection (5 experts), ecology ( 2 experts). In total, 23 experts participated in the valuation of the models.

The valuations obtained were presented in the form of local weights (importance). The weight with a value close to zero means a small amount of impact. The weight close to 1 indicates a strong impact of the project on a given item. The sum of weights at each level is $1(100 \%)$. The results are as follows: lithosphere 0.26 ; hydrosphere 0.19 ; atmosphere 0.06 ; anthroposphere 0.05 ; biosphere 0.29 ; vulnerability to natural hazards 0.15 .

Each number represents a vector corresponding to the priority percentage of every element in the overall scheme: the higher the value of the vector the more important the item is $[18,20]$.

\section{Leopold Matrix Method}

As explained earlier, the weights are used to create a Leopold matrix with the following results (table). With the data obtained from the AHP matrix we obtain the hierarchies of various elements of the environment affected by the mining project and actions having an impact on the environment. The elaboration of a Leopold matrix consists in identifying all the activities (actions) accompanying the operation of the mining project and in placing them in columns. For each activity, we use a rating (magnitude of impact) on a scale from 0 (no impact) to 5 (very strong impact). By multiplying the magnitude of impact and weights (importance) of environmental elements and by summing all the impacts, the total value of the mine's environmental impact is obtained [24,25]. 


\section{Results and Discussion \\ The Actions Analysis}

The action having a major impact on the environment is by far "Pumping industrial water" $(2,217)$ since the principal method of lithium extraction consists in pumping underground brine into the surface and filter it through different stages of evaporation and precipitation until getting the final highly-concentrated lithium carbonate that can be subjected to further processing. All this procedure has crucial impacts on the surrounding hydrosphere (Fig. 2).

Pumping large amounts of water, both brine and fresh water, for the production of lithium carbonate, interferes with groundwater networks and carries the risk of changing water flows and drawing down the water table. The plains or bogs and the lake bodies are affected by the exploitation of groundwater by mining companies. These activities alter the water cycle of the basin, prevent water recharge, lower the phreatic levels, reduce the flow of the slopes, dissect the surfaces of the plains, reduce the levels and surfaces of the lake bodies.

Given the importance of groundwater to both surface water sources and wildlife and human habitats, water resources alteration may be considered as having some social and economic impact on local communities and their overall wellbeing [1].

Plants are highly dependent on water availability and even minor changes in the water budget can result in dramatic increases or decreases in vegetation. On the other hand, the most important habitats for both flora and fauna are the arid wetlands which are less dependent on precipitation but more on the availability of groundwater.

Another item in the hierarchy with high influence on the environment is "Production of Industrial Wastes" $(1,399)$. Water is considered to be the main industrial waste product in the process of lithium processing. It has the risk of contaminating the lithosphere through leakage and drainage from leaching piles, processing ponds and tailing liquids disposal because at some stages of brine processing the brine shall be acidified with hydrochloric acid and reach a $\mathrm{pH}$ of between 3 and 4 , with the risk of acid leakage. This industrial water can pollute underground water beneath the facilities and surface water that receive their discharge water. Toxic compounds are likely to leak from these facilities, pass through the ground and affect underground water, especially if the bottom of the facility has not been protected with a waterproofing liner.

Waste from the evaporation process in the ponds leave high amounts of salts accumulated on the bottom of the ponds. These salt piles may reach $15 \mathrm{~m}$ in height. Estimations indicate that approximately 740 ha of salt piles will be built over a 40 -year period and these piles will be built near the pond areas. These accumulated salts are classified as inert waste. The salts are generated from brines already present in the salar and do not introduce foreign compounds. It is estimated that sodium chloride and sulphate make up over $87 \%$ of this waste.

Actions considered to have a lesser impact on the environment are "Production of Municipal Waste" $(0,868)$ and "Use of land" $(0,75)$. Municipal waste produced by the workers and people arriving to the facilities is inherent to every place where human activity is present. Several potential effects are the consumption of energy and materials used to make pack- aging and products that are discarded later. Surface water is polluted by garbage thrown away into wetlands, ponds, and pipes. In places where garbage is concentrated, leachates drain and contaminate underground water. Soil pollution is another potential effect. The presence of oils, greases, heavy metals and acids, among other contaminating residues, alter physical, chemical and fertility properties of the soils. Air pollution is also a potential effect: municipal solid waste left in open dumps deteriorates the quality of the air we breathe, both locally and in the surroundings, because of burns and fumes that reduce visibility; dust raised by the wind in dry periods can transport harmful microorganisms to other places, causing respiratory infections and nasal and eye irritations. Degradation of organic matter present in waste produces a mixture of gases composed mainly of methane and carbon dioxide $\left(\mathrm{CH}_{4}\right.$ and $\left.\mathrm{CO}_{2}\right)$ recognized as greenhouse gases (GHGs) that contribute to climate change.

Land use represents a relevant item. The ponds cover a large land: the total evaporation area required for the production of 40,000 tpa of lithium carbonate is 1,200 ha when including consideration for harvesting of salt deposited in the ponds. Although the excavation is only superficial, the fact of occupying a large part of land should be considered as an alteration of the environmental conditions, namely the Earth's crust. The excavation will need to be refilled and recovered afterwards, which is much easier than in the case of underground or open pit mining. Using a large portion of land can affect some living beings and alter their habitat. However, since there is plenty of land available for their living, the effect would be just a temporary migration of some of them to other areas. When the project comes to its end, the recovery of the habitat for plants and animals must be ensured, which - as mentioned previously - is less labour-intensive and easier than in the case of other extractive methods.

Other items included in the hierarchy with low environmental impact are "Pollutant emissions to the air" $(0,392)$ and "Infrastructure of Power Plants" $(0,379)$. Air pollutants are low in quantity as they are produced by diesel equipment. In comparison with open pit mining or underground mining, their impact is very low and has no high significance with one exception: the development stages of the project where more machinery is needed. The emissions from the power plant servicing the project are also low since the plant is totally powered by natural gas whose $\mathrm{CO}_{2}$ emissions are low and with no high significance compared with diesel and oil. In addition, there are backup diesel generators used in case of emergency. The infrastructure of the power plants does not affect the environment significantly, either. The habitat area they occupy is not highly altered, nor substantially affected.

Other items with none or almost none impact on the environment are "Noise and vibration" $(0,228)$, "Unpleasant odours" $(0,228)$, "Reclamation activities" $(0)$ and "Deforestation" (0). There is little noise and vibration as there is no blasting needed and a few machines are used. There are no other unpleasant odours but the ones from some salt in the ponds that might affect some living beings but with no significance in the overall scheme. Reclamation activities have no influence, and as the territory is a dry area, there is no deforestation carried on. 


\section{The Elements analysis}

As we can see in Figure 4, the most affected part of the environment is the biosphere $(2,28)$ highly impacted as a consequence of altered hydrosphere. Due to a large number of springs, the wetlands occupy an important area and are essential for camelid farming.

The groundwater system forms an internal tissue that regulates external soil moisture, which is reflected in the formation of springs, slopes, rivers, pools, lagoons and wetlands that serve as a habitat for avifauna and human populations settled in the region.

The greatest concern usually lies with the extraction of fresh water since it is necessary not only for human life but also for the plains, i.e. flora and fauna on the surface. Similarly, the extraction of brine - which is much higher - can adversely affect fresh water layers. The extraction of groundwater can result in habitat alteration for terrestrial vegetation and flora, fauna and aquatic fauna. Wildlife (e.g. birds) dependent on ponds and wetlands could be particularly affected, and camel flocks dependent on wetlands could be reduced or disappear locally.

The greatest concern is the cumulative, permanent and irreversible nature of brine extraction because the reservoir will gradually diminish and extraction will not allow a return to the original conditions. The brine levels, in turn, will be recovering for a very long period of time (geologic time). There are other potential impacts of adverse events that could contaminate the biosphere, namely the potential pollution of the soil due to leaking, waste, noise and vibration from machinery which could to some extent affect the lives of the surrounding living beings.

Next hierarchical item affected by the project is the lithosphere $(2,088)$. It has reached a very high impact level in the overall scheme because of the accumulation of several potential impacts. The main action showing the highest impact is pumping industrial water. As brine extraction is basically focused on pumping underground water, there is little alteration made to Earth's crust: a superficial excavation to create the ponds where the water is pumped; punctual drillings to create the pumping systems; roads built to facilitate the access to the area; and in some parts the surface was altered by the construction of buildings and facilities. The impact of these factors on the environment and in the overall scheme is neither serious nor permanent.

The ponds are lined with a multi-layer liner made of a polymer-based material and engineered granular bedding so that insulation is assured and filtration to the ground is avoided. Using a large portion of land can affect some living beings and alter their habitat. However, since there is plenty of land available for their living, the effect would be just a temporary migration of some of them to other areas. When the project comes to its end, the recovery of the habitat for plants and animals must be ensured, which - as mentioned previously - is less labour-intensive and easier than in the case of other extractive methods. Also, different types of waste have a high potential for contaminating the lithosphere. Municipal waste can lead to soil pollution.

Next item of the hierarchy to bear the project's impacts is the hydrosphere $(1,358)$. Pumping immense amounts of brine to the surface not only lowers the brine level, but also depress- es fresh groundwater in the basin. There is the risk of degrading the locally formed meadows and lagoons being an essential water resource to the region. It is considered that $80 \%$ of the water, so-called "fossil water" will not be renewed with contemporary rainfall because it originated in much more humid climatic conditions. As the modern water recharge is very limited, water may rise very slowly or the place may be even considered as a non-renewable water resource. Given the aridity of the area, which is insufficient to recharge the water aquifers, which in many cases are of non-renewable origin, and the possible impact that the extraction of brine and water has on the water table, extraction levels should be of major concern and must be consistently overviewed.

Waste water as industrial waste has the risk of contaminating the lithosphere. When it comes to municipal waste, surface water is polluted by garbage discarded into the wetlands, ponds and pipes. In places where garbage is concentrated, leachates are filtered out and contaminate the underground water.

Next element of the hierarchy to be affected to a small extent is the atmosphere $(0,354)$. The main pollutants are sand and gravel because of the excavations and transport taking place before the construction of access roads; then there are greenhouse gases (CO2) emitted by diesel equipment and transport vehicles. However, all these factors were only temporary and had their impact at the stage of building the facility and infrastructure. Nonetheless, even at that time their environmental impact was not significant.

In the operational phase of the project, there are still emissions from diesel vehicles reaching the area, but they have a small environmental impact because the need for transport to the zone is very low due to a small number of workers required to the project. The plant includes a diesel storage and dispensing station for mobile equipment and transport vehicles. Diesel fuel will also be used in stand-by generators and back up for dryers in the plant. The equipment will be mainly fuelled with natural gas obtained from the Rosario gas compression station which is on the Gas Atacama pipeline, $52 \mathrm{~km}$ north of the project site.

The anthroposphere $(0,23)$ is least affected item despite the fact that local communities are trying to express their opposition through the media. Given the importance of groundwater to both surface water sources and wildlife and human habitats, water resources alteration may be considered as having some social and economic impact on local communities and their overall wellbeing.

The population near the territory consists of relatively small and dispersed groupings, often suffering from poor infrastructure and high rates of material poverty. They are characterized by a close relationship with the natural environment, and their integrity and reproduction depend on nature, given that their main form of economic support is livestock or agriculture, and nature around the ecosystem forms part of their cultural heritage. However, they do not live in isolation, nor outside the market economy, since they not only use the products of these activities for sale or barter with other regional products, but also complement their livelihood with wage work in mining or tourism. Finally, they have or aspire to legal recognition of indigenous territories with community control over land and natural resources. 
The socio-economic and cultural impacts on the local population whose main activity is camelid farming based on the bogs, and whose culture is closely related to water is one of the main concerns. Also the disappearance or degradation of drinkable water sources (wells and springs) located near the points of lithium extraction, or coming from the same aquifers is going to affect drinkable water supplies.

In the early phases of the project some conflicts arouse between local communities and companies because the latter failed to provide information to local representatives [1].

Another important socio-economic aspect is that even though companies usually claim that in the long term their projects are going to generate employment and capacity for the community, the experience so far shows that lithium mining itself generates very few jobs in the mining regions since conventional evaporation technology is not very labour-intensive. About 500 workers are usually needed for the construction of industrial plants while during production the number decreases to about 200 people with little involvement of local employees [2].

When national or sub-national states fail to comply with established laws such as the right to consultation and participation, local communities lose control over the territory without their consent. This is reflected in the fact that local populations have little access to concrete information about projects and are characterized by uncertainty, sharing concerns about water, the resource by which their main productive activities depend on [3].

The last item with very little impact and no significance in the overall scheme is vulnerability to natural hazards $(0,151)$. The only probable potential risk is the appearance of torrential rainfall events in the wet season that could cause the ponds to overflow.

\section{Conclusions}

Mining for the mineral puts pressure on the environment. The scale of the transformation of the environment depends on the area occupied, the location of the deposit within the natural habitat, and the sensitivity of the species to changes in nature. During the exploitation of deposits, the relief of the land is strongly transformed, the soil cover and vegetation are removed, and adverse erosion processes occur. Mining operations have a significant impact on the landscape of the surrounding areas [23].

Some stages of exploitation are very burdensome for the environment. At the preparatory stage, the overburden is removed, vegetation is destroyed and the land is prepared for exploitation. The natural habitats are irretrievably destroyed and the vegetation undergoes degradation. Some animal species lose their habitats and others, deterred by the noise of working equipment, move to other places.
The study case concerning the extraction of brine and its processing into high-purity lithium carbonate by Lithium Americas at the Cauchari and Olaroz Salars showed that it is the hydrosphere that is most affected by these operations. Pumping the brine to the surface on an industrial scale disturbs the balance of water bodies. As a result, the groundwater table is drawn down and resources in surface reservoirs are depleted. The exploitation of water requires careful analysis in order to eliminate or mitigate negative effects on ecosystems. The availability of groundwater is a prerequisite for the occurrence of flora, terrestrial and aquatic fauna habitats. Even small changes in the water balance can cause a dramatic decline in plant vegetation [10].

The Cauchari and Olaroz Salars cover a large area of land, which should be regarded as a transformation of the earth's crust. A large part of the lithosphere is covered by evaporative ponds. Leakage and drainage from ponds and tailing liquids disposal are a source of lithospheric pollution. Soil contamination by heavy metals, acids and grease contained in municipal waste is observed. Once the mineral has been used, plant and animal habitats will need to be restored and rehabilitated.

The paper demonstrated that processing the brine into lithium carbonate at the Olaroz Salars has negative consequences. However, as long as the mining is carried out correctly, in a manner consistent with the idea of sustainable development, and the rehabilitation is carried out in the right direction, it can bring many benefits for people and the environment [26]. The positive impact of mining is reflected in the creation of new habitats for plants and animals in the post-mining areas and in landscape diversification activities.

\section{Author Contributions}

Conceptualization: W.S. ,K.C. and E.S.; methodology, W.S.; formal analysis: W.S.; investigations: K.C.; writing original draft preparation: E.S., W.S. and K.C.; writing - review and editing: W.S., E.S. and K.C.; visualization: E.S. and K.C.; supervision: W.S. Authors have read and agreed to the published version of the manuscript.

\section{Funding}

Publication financed by the subsidy granted to the Faculty of Mining and Geoengineering, AGH University of Science and Technology. Publication was carried out as part of the statutory activity of the Mineral Energy and Economy Research Institute of the Polish Academy of Sciences.

\section{Conflicts of Interest}

The authors declare no conflict of interest. 


\section{Literatura - References}

1. Burga, E., Burga, D., Weber, D., Genck, W. and Sanford, A. (2019), Technical Report NI 43-101, Updated Feasibility Study and Mineral Reserve Estimation to Support Lithium Carbonate Production at the Cauchari-Olaroz Salars. Lithium Americas Corp. Cauchari Salars. Argentina.

2. Burga, E., Burga, D., Genck, W. and Weber, D. (2019), Updated Mineral Reserve Estimate For the Cauchari-Olaroz Project, Jujuy Province, NI 43-101 Report, Prepared for Lithium Americas. Argentina.

3. Salazar, G.A. (2019), Análasis estadístico de datos meteorólogicos medidos y de tendencia de evaporación en Salar Cauchari-Olaroz (Prov. de Jujuy-Argentina) INENCO-CONICET. Reporte. Argentina.

4. ARA WorleyParsons (2011), Preliminary Assessment and Economic Evaluation of the Cauchari-Olaroz Lithium Project, Jujuy Province. Argentina.

5. Piecuch, I. and Hewelt, T.G. (2013), Environmental Education - First Knowledge and Then the Habit of Environment Protection. Ann. Set Env. Prot., 15, 136-150.

6. Oca Pérez, A.M. (2014), Ontología de Evaluación de Impacto Ambiental para proyectos mineros. Available online: https://www.ecured.cu/Comisión_Mundial_sobre_Medio_Ambiente_y_Desarrollo (accessed on 15 Sept. 2020).

7. United Nations General Assembly (2019), Hacia un planeta sin contaminación. Asamblea de las naciones unidas sobre el medio ambiente del programa de las naciones unidas para el medio ambiente. 28 March 2019. UNEP/ EA.3/25.

8. Pastor Aberturas, D.A. (2017), La evaluación de impacto ambiental en minería: Estudio Preliminar de Impacto Ambiental. Universidad de Oviedo Escuela de Ingeniería de Minas, Energía y Materiales Máster Universitario en Ingeniería de Minas. Oviedo.

9. Rodríguez, E., Antonio, J., Contreras, S. and Luis, J. (2013), An Assessment of Lithium Resources. Lithium: Technol, Perform and Safety,1-34.

10. Ahmad, S. (2020), The Lithium Triangle: Where Chile, Argentina, and Bolivia Meet. Harvard International Rev 15 Jan. 2020. Available online: https://hir.harvard.edu/lithium-triangle (accessed on 10 Sept. 2020).

11. Marchegiani, P., Höglund Hellgren, J. and Gómez, L. (2019), Extracción de Litio en Argentina: un estudio de caso sobre los impactos sociales y ambientales. FARN Fundación Ambiente y Recursos Naturales.

12. Sticco, M. (2018), El impacto de la explotación del litio en las reservas de agua dulce. Provincia de Jujuy, Argentina. Conversatorio El impacto del litio en las reservas de agua. UNJU.

13. Sun, X., Han, H., Zhao, F. and Liu, Z. (2017), Tracing global lithium flow: A trade-linked material flow analysis. Res., Conserv \& Rec., 124, 50-61.

14. Ortiz, C., Aravena, R., Briones, E., Suárez, F., Tore, C. and Muñoz, J.F. (2014), Sources of surface water for the soncor ecosystem, salar de Atacama basin, Northern Chile. Hydrol Sci J;59(2):336-350. Available online : https:// search.proquest.com/docview/1503760246 (accessed on 2 Sept. 2020).

15. Dirección de Economía Minera (2017), Situación actual y perspectivas: Mercado de Litio. Informe especial. Ministerio de Energía y Minería.

16. Galos, K., Tiess, G., Kot-Niewiadomska, A., Muruoia, D. and Wertichowa, B. (2018), Mineral Deposits of Public Importance (MDoPI) in relation to the Project of the National Mineral Policy of Poland. Miner. Res. Manag., 34(4), $5-24$.

17. Mancini, L. and Sala, S. (2018), Social impact assessment in the mining sector. Review and comparison of indicators framework. Res. Policy, 57, 98-111.

18. Nieć, M. and Radwanek-Bąk, B. (2011), Ranking value of industrial rocks deposits. (in Polish, with English abstract). Górn. Odkrywk., 52(6), 5-15.

19. Nieć, M. and Radwanek-Bąk, B. (2014), Valorisation of undeveloped industrial rock deposits in Poland. Res. Policy, 45, 290-295. Available online: http://dx.doi.org./10.1016/resourpol (accessed on 24 August 2020).

20. Radwanek-Bąk, B. (2006), The concept of multi-criteria mineral resources protection. Environmental Geol., 52, 137-145.

21. Saaty, T.L. (1977), Scaling Method for Priorities in Hierarchical Structures. Journ. Math. Psych., 15, $234-281$.

22. Saaty, T.L. (2004), Decision making the Analytic Hierarchy and Network Processes (AHP/ANP). J of Systems Sci. and Systems Engin., 13(1).

23. Sobczyk, E.J., Wota, A. and Krężołek, S. (2011), The use of mathematical multi-criteria methods to select the optimal variant of the source of hard coal. Miner Res Manag., 3, 51-68. 
24. Sobczyk, W., Sobczyk, E.J. and Kowalska, A. (2014), The use of AHP multi-criteria method and Leopold matrix to assess the impact of gravel and sand pits on the environment of the Jasiolka Valley. Miner Res Manag., 30(2), $157-172$.

25. Wringhton, C.E., Bee, E.J. and Mankelow, J.M. (2014), The development and implementation of mineral safeguarding policies at national and local levels in the United Kingdom. Res. Policy, 41(1), 160-170. Available online: https://doi.org/10.1016/jresourpol.2014.05.006 (accessed on 15 Sept. 2020).

26. Sobczyk, E.J., Kicki, J., Sobczyk, W. and Szuwarzyński, M. (2017), Support of mining investment choice decisions with the use of multi-criteria method. Res Policy, 51, 94-99.

\section{Ocena rzeczywistego ryzyka oddziaływania przemysłu wydobywczego na środowisko. Studium przypadku}

Celem artykulu jest analiza rzeczywistego ryzyka, jakie eksploatacja górnicza stwarza dla środowiska, z uwzględnieniem wszystkich głównych czynników związanych z planowanymi działaniami w projekcie i ich oddziaływaniem na środowisko.

W celu przeprowadzenia dogłębnej analizy przypadku praktycznego dotyczacego rzeczywistego procesu wydobycia minerałów, jako metody pomiaru wykorzystano Analytic Hierarchy Process (AHP) - wielokryterialnaq metodę hierarchicznej analizy problemów decyzyjnych oraz macierz Leopolda.

Przedmiotem badań jest eksploatacja litu z naturalnej solanki znajdującej się w tzw. Trójkacie Litowym Ameryki Południowej, w granicach geograficznych Argentyny, Boliwii i Chile, gdzie znajduje się ponad 80\% światowych zasobów litu. Studium przypadku wykazało, że elementami środowiska najbardziej narażonymi na działalność górnicza sa biosfera, litosfera i hydrosfera. Rozległe tereny przedsiębiorstwa górniczego pokrywaja stawy osadowe z solanką. Wypompowanie solanki na powierzchnię powoduje utratę zasobów wód podziemnych i w konsekwencji zmianę obiegu wody w zlewni. Siedliska fauny i flory wodnej i lądowej ulegaja znacznym zmianom lub nieodwracalnym uszkodzeniom.

Słowa kluczowe: działalność górnicza, lit, środowisko, AHP, macierz Leopolda 